\title{
Pathology of deaths associated with "ecstasy" and "eve" misuse
}

\author{
C M Milroy, J C Clark, A R W Forrest
}

\begin{abstract}
Aims-To study the postmortem pathology associated with ring substituted amphetamine (amphetamine derivatives) misuse.

Methods-The postmortem findings in deaths associated with the ring substituted amphetamines 3,4-methylenedioxymethylamphetamine (MDMA, ecstasy) and 3,4methylenedioxyethylamphetamine (MDEA, eve) were studied in seven young white men aged between 20 and 25 years.

Results-Striking changes were identified in the liver, which varied from foci of individual cell necrosis to centrilobular necrosis. In one case there was massive hepatic necrosis. Changes consistent with catecholamine induced myocardial damage were seen in five cases. In the brain perivascular haemorrhagic and hypoxic changes were identified in four cases. Overall, the changes in four cases were the same as those reported in heat stroke, although only two cases had a documented history of hyperthermia. Of these four cases, all had changes in their liver, three had changes in their brains, and three in their heart. Of the other three cases, one man died of fulminant liver failure, one of water intoxication and one probably from a cardiac arrhythmia associated with myocardial fibrosis.

Conclusions-These data suggest that there is more than one mechanism of damage in ring substituted amphetamine misuse, injury being caused by hyperthermia in some cases, but with ring substituted amphetamines also possibly having a toxic effect on the liver and other organs in the absence of hyperthermia.

(f Clin Pathol 1996;49:149-153)
\end{abstract}

Department of Forensic Pathology, University of Sheffield, Sheffield

C M Milroy

J C Clark

A R W Forrest

Department of Clinical Chemistry, Royal Hallamshire Hospital, Sheffield A R W Forrest

Correspondence to: Dr C M Milroy, Department

of Forensic Pathology,

The Medico-Legal Centre

Watery Street,

Wheffield S3 7ES.

Accepted for publication

18 October 1995
Keywords: eve, ecstasy, postmortem pathology.

Recreational use of 3,4-methylenedioxymethylamphetamine (MDMA), more commonly known as "ecstasy" (and a variety of other names including "XTC", "Adam" or " $E$ "), is now well established. In Britain upwards of 500000 people are said to use the drug each week (Harris Poll (1992) for "Reportage", $\mathrm{BBC} 2$, 22 Jan 1993).

MDMA is a ring substituted amphetamine with psychoactive properties. First synthesised in 1914 from methylenedioxyamphetamine (MDA), itself a drug of misuse (known as the "love drug"), it has been used in psychotherapy and was originally used as an appetite sup- pressant. The drug has ceased to be used medicinally and is now an established part of the illegal drug scene. It is banned in most countries. In the UK it is a class A drug as defined in Schedule 2 of the Misuse of Drugs Act 1971. It has no medicinal use in the UK and cannot be prescribed. As well as MDA and MDMA, another variant, methylenedioxyethylamphetamine (MDEA, known as "eve"), which is similarly proscribed, is commonly encountered. All have similar pharmacological effects.

In the UK, MDMA is often taken by young people at discos and rave parties. Both involve dancing, but especially at the latter there is vigorous repetitive dancing in crowded rooms with a hot and humid atmosphere. The dangers of this activity are recognised to a certain extent as rooms to "chill out" are often available for people to rest in after periods of exertion. Toxic effects and the occasional death following ring substituted amphetamine misuse have been reported but postmortem data are lacking. ${ }^{1-26}$ In this paper we report on deaths associated with ring substituted amphetamine misuse and detail the postmortem findings.

\section{Methods}

Seven deaths have been investigated by the University of Sheffield Department of Forensic Pathology in the past three years, which were associated with ring substituted amphetamine misuse. One case has been reported previously. ${ }^{26}$ Case details are presented in table 1. All of the subjects were white men, between 20 and 25 years of age. Three of the victims collapsed at a rave or disco, two were found in bed, one in a collapsed state and one dead, one collapsed in the street, and one was admitted to hospital with progressive jaundice.

Only two of the men had documented hyperthermia, with temperatures of $44^{\circ} \mathrm{C}$ and $39.5^{\circ} \mathrm{C}$. One of the deaths was thought to have been caused by water intoxication, the victim having drunk an estimated 14 litres of water in trying to quench the thirst that is frequently associated with ingestion of ring substituted amphetamines. None of the men were known intravenous drug abusers.

Full drug screening was performed on body fluids, including a screen for drugs of abuse. Screening by gas chromatography/mass spectroscopy was also performed.

\section{Results}

\section{PATHOLOGY}

The pathological and toxicological data are summarised in table 1. 
Table 1 Clinical features, toxicology and postmortem findings

\begin{tabular}{|c|c|c|c|c|}
\hline $\begin{array}{l}\text { Case } \\
\text { no. }\end{array}$ & $\begin{array}{l}\text { Age } \\
\text { (years) }\end{array}$ & Clinical data & $\begin{array}{l}\text { Toxicology } \\
\text { (blood concentrations) }\end{array}$ & Pathology \\
\hline 1 & 21 & $\begin{array}{l}\text { Collapsed at rave. Agitation, } \\
\text { unconscious, } 44^{\circ} \mathrm{C} \text {, cardiac arrest }\end{array}$ & $\begin{array}{l}\text { MDMA }(4 \cdot 2 \mathrm{mg} / \mathrm{l}) \\
\text { Amphetamine }(1 \cdot 4 \mathrm{mg} / \mathrm{l})\end{array}$ & $\begin{array}{l}\text { Heart-contraction band necrosis } \\
\text { Liver-focal necrosis } \\
\text { Brain-focal haemorrhage, } \\
\text { neuronal degeneration }\end{array}$ \\
\hline 2 & 20 & $\begin{array}{l}\text { Collapsed at disco. Thirst, convulsions, } \\
36^{\circ} \mathrm{C}, \uparrow \mathrm{BP} \text {, low } \mathrm{Na}^{+} \text {, unconscious. } \\
\text { Water intoxication }\end{array}$ & $\operatorname{MDMA}(0.04 \mathrm{mg} / \mathrm{l})$ & $\begin{array}{l}\text { Heart-widespread foci of necrosis } \\
\text { Liver-foci of necrosis } \\
\text { Brain-gross oedema, focal } \\
\text { haemorrhage. } \\
\text { Pituitary necrosis }\end{array}$ \\
\hline 3 & 24 & $\begin{array}{l}\text { Collapsed and died at disco. ? } \\
\text { Temperature }\end{array}$ & $\begin{array}{l}\text { MDEA }(0.187 \mathrm{mg} / \mathrm{l}) \\
\text { Amphetamine }(0.453 \mathrm{mg} / \mathrm{l})\end{array}$ & $\begin{array}{l}\text { Heart-focal necrosis } \\
\text { Liver-focal necrosis }\end{array}$ \\
\hline 4 & 21 & $\begin{array}{l}\text { Found dead in bed after party. No } \\
\text { symptoms }\end{array}$ & $\begin{array}{l}\text { MDMA }(2.1 \mathrm{mg} / \mathrm{l}) \\
\text { MDEA }(3.5 \mathrm{mg} / 1) \\
\text { MDA }(8.5 \mathrm{mg} / \mathrm{l}) \\
\text { Amphetamine }(0.256 \mathrm{mg} / \mathrm{l})\end{array}$ & $\begin{array}{l}\text { Heart-normal } \\
\text { Liver-focal necrosis } \\
\text { Brain-focal haemorrhage } \\
\text { Inhalation of vomit }\end{array}$ \\
\hline 5 & 20 & $\begin{array}{l}\text { Found unconscious in bed. Rigidity, } \\
39 \cdot 5^{\circ} \mathrm{C}, \uparrow \mathrm{LFTs} \text {, cerebral hypoxia. } \\
\text { Survived four days }\end{array}$ & $\begin{array}{l}\text { MDMA }(0.09 \mathrm{mg} / \mathrm{l}) \\
\text { MDA }(0.13 \mathrm{mg} / \mathrm{l})\end{array}$ & $\begin{array}{l}\text { Heart - widespread foci of necrosis } \\
\text { Liver-extensive necrosis } \\
\text { Brain-hypoxic changes, DIC } \\
\text { Lung-pulmonary infacts }\end{array}$ \\
\hline 6 & 25 & $\begin{array}{l}\text { Sudden collapse in street. Previously } \\
\text { well, witnessed collapse. Brought in } \\
\text { dead }\end{array}$ & $\begin{array}{l}\text { MDMA (trace in urine) } \\
\text { MDA (trace in urine) }\end{array}$ & $\begin{array}{l}\text { Heart-widespread foci of necrosis } \\
\text { Liver-focal necrosis }\end{array}$ \\
\hline 7 & 23 & $\begin{array}{l}\text { Progressive jaundice and liver failure. } \\
\text { All investigations negative. Admitted } \\
\text { heavy ecstasy use, even after onset of } \\
\text { jaundice }\end{array}$ & Admitted regular ecstasy use & $\begin{array}{l}\text { Heart-normal } \\
\text { Liver-massive hepatic necrosis } \\
\text { Brain-normal }\end{array}$ \\
\hline
\end{tabular}

LFTs $=$ liver function tests

\section{Liver}

The liver showed dramatic changes. Necrosis was seen in all cases. In one case there was centrilobular and midzonal necrosis (fig 1). This patient survived for four days. In the other cases focal necrosis in zone 3 was present, with an acute inflammatory response surrounding necrotic hepatocytes (fig 2). Fatty change, sinusoidal dilatation and inflammation were also identified. No other hepatic pathology was identified in these cases. Postmortem virology was not done in these cases. In case 7 there was massive hepatic necrosis, with the liver only weighing $795 \mathrm{~g}$ at necropsy. Full viral screening was negative in this case. The livers were of normal size in the other cases.

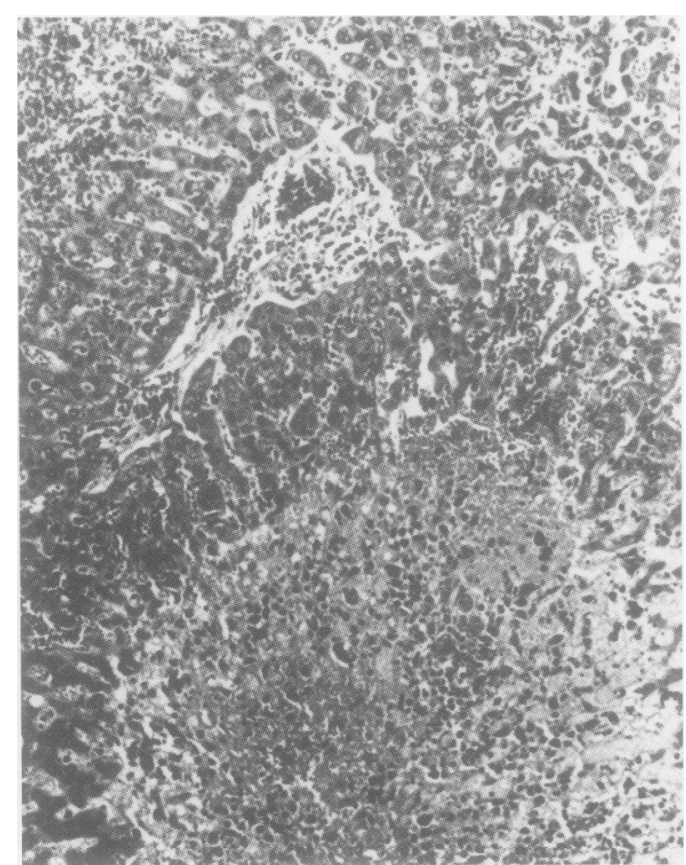

Figure 1 Section of liver showing centrilobular and midzonal necrosis following ingestion of "ecstasy".
Heart

Changes were seen in five of the seven hearts examined. Histologically, the changes ranged from contraction band necrosis to individual myocyte necrosis with a surrounding neutrophil and macrophage inflammatory response; the same changes as have been described in catecholamine induced myocardial injury (fig 3). In one case foci of fibrosis were identified in the heart of a man in whom traces of MDMA and MDA were found in the urine.

\section{Brain}

The brain of one of the cases of rapid death showed disseminated intravascular coagulation (DIC), oedema and degeneration of neurones, particularly apparent in the locus ceruleus. Two cases showed foci of haemorrhage (fig 4). One case showed severe cerebral oedema consistent with water intoxication and had additional occasional perivascular haemorrhages.

\section{Other organs}

Pulmonary infarction was seen in case 5. In two of the other rapid deaths intra-alveolar haemorrhage was present. In one case there was inhalation of gastric contents. In the patient who died of water intoxication there was complete necrosis of the pituitary gland. Severe cerebral oedema was present and the pituitary necrosis was probably a direct consequence of this as the blood supply was compromised. In two cases the kidneys were examined for myoglobin, which was not detected. No skeletal muscle damage was identified.

\section{TOXICOLOGY}

The toxicological data are shown in table 1 . MDMA was found in five cases, varying from trace concentrations to $4 \cdot 2 \mathrm{mg} / 1$. MDEA was found in two cases, at concentrations of 3.5 and $0.187 \mathrm{mg} / 1$. Amphetamines were detected in three cases at concentrations of $0 \cdot 256,0 \cdot 453$ 


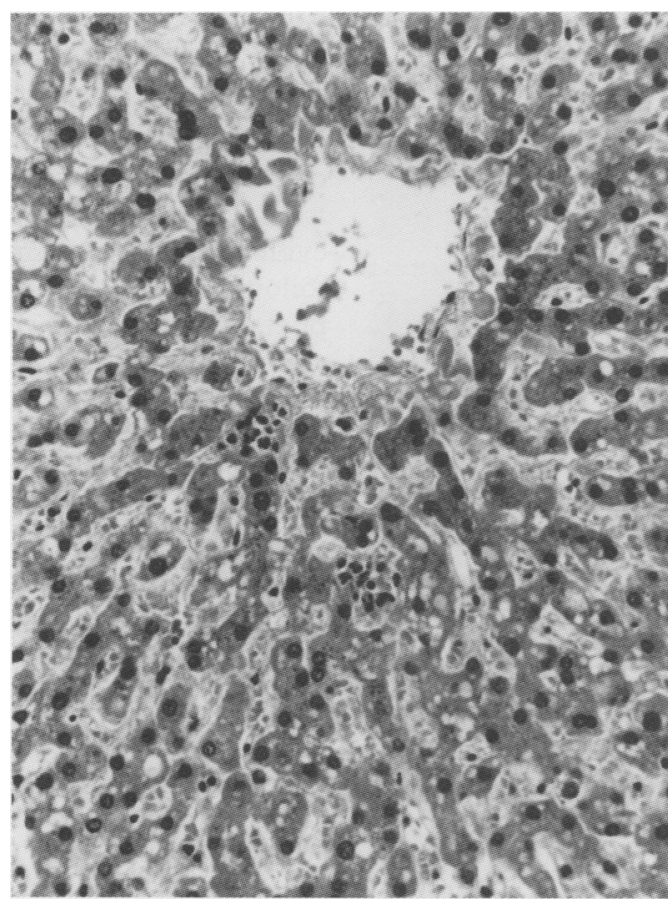

Figure 2 Section of liver showing foci of individual hepatocyte necrosis following ingestion of "ecstasy". Fatty change and sinusoidal dilatation are present.

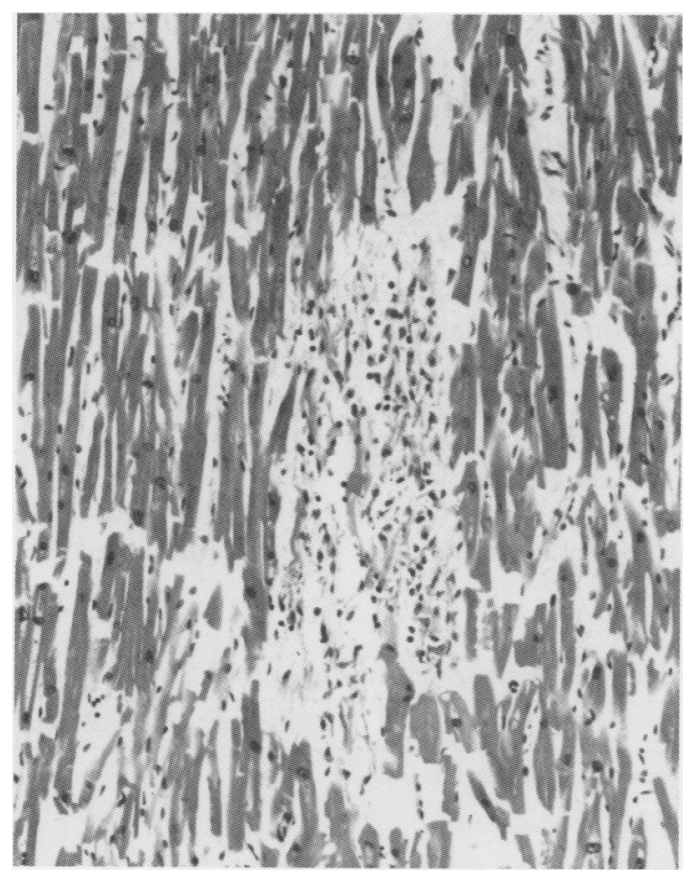

Figure 3 Myocardial necrosis following ingestion of "ecstasy".

and $1.4 \mathrm{mg} / \mathrm{l}$. MDA was found in three cases, varying from trace concentrations to $8.5 \mathrm{mg} / \mathrm{l}$. MDA is a metabolite of MDMA and MDEA, but may also be found as a constituent of "ecstasy" tablets, along with other pharmacological substances including amphetamines (vide infra). No opiates or other drugs associated with intravenous drug abuse were detected.

\section{Discussion}

Ring substituted amphetamines (amphetamine derivatives) are taken because they give a feeling of euphoria and benevolence and heighten the sensations at raves and discos. However, when 29 volunteers took MDMA, as well as pleasant symptoms, all complained of undesirable effects which included loss of appetite, trismus and bruxism, nausea, muscle aches, stiffness, and ataxia. ${ }^{27}$ Sweating, tachycardia and hypertension, insomnia, and fatigue were also reported. More serious complications reported include hyperthermia, convulsions, other cardiac arrhythmias, rhabdomyolysis, disseminated intravascular coagulation, renal failure, hyponatraemia, hepatoxicity, pneumomediastinum, aplastic anaemia, cerebral infarction, cerebral haemorrhage, and cerebral venous sinus thrombosis. ${ }^{1-26}$

In five of the cases reported here complications followed shortly after ingestion. Four of these deaths seem to be linked directly to the toxic effects of MDMA and MDEA. In the fifth case there was evidence of water intoxication, which followed the taking of "ecstasy". In this case, however, myocardial and liver pathology was identified which was similar to the other cases. The sixth case collapsed in the street. Myocardial fibrosis and foci of liver necrosis were identified and toxicology revealed traces of MDMA.

MDMA is believed to act on at least three neurotransmitter pathways, as does cocaine, but with MDMA the serotoninergic (5-hydroxytryptamine) pathway is principally affected, which would account for the more pronounced effect on mood. Cocaine acts chiefly on the dopaminergic system, which accounts for its greater addictive properties. MDMA also acts on the noradrenergic system. Serotonin plays a major role in thermoregulation and interference with this mechanism is believed to be the cause of the hyperthermia which arises as a complication of ring substituted amphetamine misuse. Stimulation of the noradrenergic system also probably contributes to hyperthermia.

Hyperthermia may account for many of the changes seen in deaths from ring substituted amphetamine misuse, although it is interesting to note that raised temperatures were only documented in two of our cases.

The pathology of heatstroke has been reported in a number of papers. ${ }^{28-34}$ In the liver the most striking change is centrilobular necrosis. Sinusoidal congestion and dilatation, and portal and sinusoidal inflammation may be present. Fatty change has been reported occasionally. Cholestasis may be present, especially in fatal cases. Rubel and Ishak $^{34}$ did not find liver necrosis as frequently as other authors. They examined the liver in 50 military recruits who had died of heatstroke. These men were predominantly white. Kew et $a^{\beta 1}$ had found liver necrosis a common finding in black South African gold miners. The difference in frequency may be related to the fact that the gold miners work in very high environmental temperatures with over $90 \%$ humidity, conditions not dissimilar to some raves and discos.

In the myocardium contraction band necrosis and small foci of necrosis with a mixed inflammatory infiltrate are seen. These features are also evident in catecholamine induced injury. In the brain ring haemorrhages and hyp- 


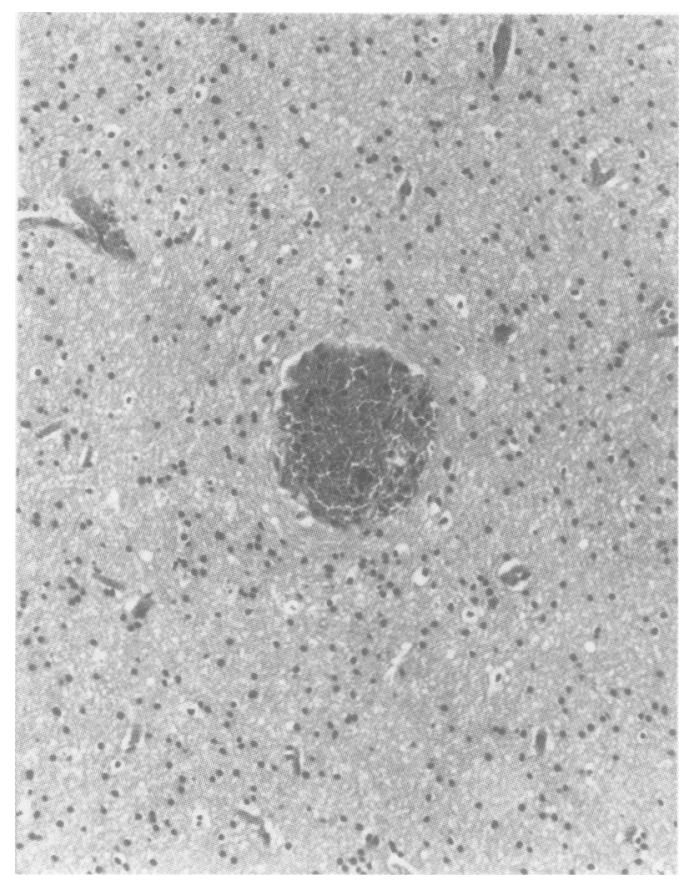

Figure 4 Perivascular haemorrhage in the cerebral cortex following ingestion of "ecstasy".

oxic changes have been described. The kidneys may show acute tubular necrosis and pulmonary haemorrhage is common.

The mechanism of damage in heatstroke is postulated to be caused by circulatory collapse and hypoxic damage, possibly combined with disseminated intravascular coagulopathy, which has been recorded in heatstroke, ${ }^{3637}$ and as a complication of MDMA and amphetamine ingestion. ${ }^{37}$ In the myocardium the damage may be related to catecholamine induced injury. These myocardial changes are also seen secondary to brain pathology, and contraction band necrosis may be seen in resuscitation, especially when catecholamines are used. Whilst these are alternative explanations for the changes seen, not everyone was resuscitated, and the myocardial changes are frequently seen, even in early deaths.

The pathological changes present in these deaths are the same as those seen in deaths from heatstroke. These changes provide further evidence that hyperthermia can cause death following misuse of ring substituted amphetamines. Evidence of disseminated intravascular coagulopathy was also present in the brain. These deaths may therefore be a complication of hyperthermia, DIC and shock. Some caution must be exercised, however, in ascribing a death from ring substituted amphetamine misuse to these mechanisms as a high temperature is not recorded in all cases, although hyperpyrexia may have been present at some time.

In the seventh case death was caused by fulminant liver failure and postmortem examination revealed massive hepatic necrosis. All investigations for the cause of liver failure were negative. The young man admitted to regular and heavy ecstasy use, and this case is similar to cases described by Henry et al. ${ }^{7}$ There is increasing evidence that "ecstasy" is hepatotoxic, and liver changes have been reported following biopsy. ${ }^{1011}$ These changes, however, differed from those found in the acute deaths described above. Whether the damage is caused by an idiosyncratic reaction to MDMA, or a contaminant of the drug is unclear. Therefore, there seems to be a second mechanism for liver injury from ring substituted amphetamines unrelated to hyperthermia. Furthermore, the possibility that the myocardium may also be damaged by these drugs without documented hyperthermia is suggested by case 6 and other reports, where myocardial fibrosis has been reported following misuse of MDMA. ${ }^{3}$

Individual susceptibility to ring substituted amphetamines may be related to its metabolism

Table 2 Description and composition of street drugs allegedly containing "ecstasy"

\begin{tabular}{|c|c|c|c|c|}
\hline Street name & Appearance & Size $(\mathrm{mm})$ & Weight (mg) & Active drug (mg) \\
\hline Adam \& Eve & $\begin{array}{l}\text { Round white tablet, E/A on one } \\
\text { surface }\end{array}$ & $12 \times 2$ & 380 & MDEA (56) \\
\hline California Sunrise & Round, scored off white tablet & $11 \times 4$ & 410 & \multirow{11}{*}{$\begin{array}{l}\text { Amphetamine }(22) \\
\text { Caffeine } \\
\text { Amphetamine }(6 \cdot 2) \\
\text { Caffeine } \\
\text { MDEA }(0 \cdot 2) \\
\text { Amphetamine }(0 \cdot 36) \\
\text { Triprolidine } \\
\text { Pseudoephedrine } \\
\text { MDA (56) } \\
\text { MDEA }(0 \cdot 52) \\
\text { MDEA }(32) \\
\text { MDMA }(0 \cdot 33) \\
\text { MDEA }(0 \cdot 18) \\
\text { Amphetamine (4) } \\
\text { Caffeine } \\
\text { Pseudoephedrine } \\
\text { MDA }(178) \\
\text { MDEA }(0 \cdot 16) \\
\text { Triprolidine } \\
\text { Pseudoephedrine } \\
\text { MDEA (57.2) } \\
\text { MDA }(0 \cdot 41) \\
\text { MDMA }(0 \cdot 21) \\
\text { MDEA }(75) \\
\text { MDMA }(12) \\
\text { MDA }(0 \cdot 59) \\
\text { Triprolidine } \\
\text { Pseudoephedrine } \\
\text { MDA (1.44) }\end{array}$} \\
\hline Green Burger & Round grey green speckled tablet & $10 \times 2$ & 300 & \\
\hline Love Heart & Round white tablet, heart on back & $8 \times 3$ & 120 & \\
\hline MDMA Capsule & White capsule & $5 \times 17$ & 190 & \\
\hline Power Pack & Biconvex, scored white tablet & $8 \times 5$ & 300 & \\
\hline Red Devil & $\begin{array}{l}\text { Round tablet, pink and white with } \\
\text { grey speckles }\end{array}$ & $10 \times 2$ & 340 & \\
\hline $\begin{array}{l}\text { Snowball } \\
\text { Split }\end{array}$ & $\begin{array}{l}\text { Biconvex white tablet } \\
\text { Round white scored tablet }\end{array}$ & $\begin{array}{l}8 \times 4 \\
8 \times 2\end{array}$ & $\begin{array}{l}390 \\
200\end{array}$ & \\
\hline Triple X & $\begin{array}{l}\text { Round scored tablet, white with black } \\
\text { speckles }\end{array}$ & $8 \times 4$ & 260 & \\
\hline White Burger Saucer & Round grey \& white speckled tablet & $11 \times 2$ & 390 & \\
\hline White Cally & Round white tablet & $8 \times 2$ & 190 & \\
\hline White Cap & Dirty white capsule & $15 \times 5$ & 280 & \\
\hline
\end{tabular}


in the liver. Abnormalities have been reported in demethylation in susceptible individuals, related to human debrisoquine hydroxylase (CYP2D6) ${ }^{38}$ Another problem for the recreational drug taker is the quality of the tablets they take. Examination of "ecstasy" tablets by one of the authors (ARWF) has shown that the contents of the tablets vary greatly, and may be a mixture of MDA, MDMA, MDEA, amphetamines, or no pharmacologically active substance; compounds such as potassium chlorate may also be found (table 2). With such material the possibility of toxic contaminants being present is evident.

The short term risks of "ecstasy" use are becoming increasingly more apparent and questions must be asked about the long term effects on the brain, liver and heart considering the pathology found in those who die.

1 Dowling GP, McDonough E, Bost R. "Eve" and "ecstasy". A report of five deaths associated with the use of MDEA and MDMA. FAMA 1987;257:1615-17.

2 Brown C, Osterloh J. Multiple severe complications from recreational ingestion of MDMA ("Ecstasy"). $\Im A M A$ 1987;258:780-1.

3 Suarez RV, Riemersma R. "Ecstasy" and sudden cardiac death. Am 7 Forensic Med Pathol 1988;9:339-41. 4 Chadwick IS, Curry PD, Linsley A, Freemont AJ, Doran
B. Ecstasy, 3-4 methylenedioxymethamphetamine (MDMA), a fatality associated with coagulopathy and hyperthermia. $\mathcal{F} R$ Soc Med 1991;84:371.

5 Screaton GR, Singer M, Cairns HS, Thrasher A, Sarner $M$, Cohen SL. Hyperpyrexia and rhabdomyolysis after MDMA ("ecstasy") abuse. Lancet 1992;339:677-8.

6 Woods JD, Henry JA. Hyperpyrexia induced by 3,4-methylenedioxyethamphetamine ("Eve"). Lancet 1992;340: 305.

7 Henry JA, Jeffreys KJ, Dawling S. Toxicity and deaths from 3,4-methylenedioxymethamphetamine ("ecstasy"). Lancet 1992;340:384-7.

8 Henry JA. Ecstasy and the dance of death. BMF 1992;305: $5-6$.

9 Fahal IB, Sallomi DF, Yaqoob M, Bell GM. Acute renal failure after ecstasy. $B M \mathcal{F}^{1992 ; 305: 29 .}$

10 Shearman JD, Chapman RWG, Satsangi J, Ryley NG, Weatherhead S. Misuse of ecstasy. BMF 1992;305:309.

11 Gorrard DA, Davies SE, Clark ML. Misuse of ecstasy. $B M \mathcal{F}$ 1992;305:309.

12 Harries DP, de Silva RN. Ecstasy and intracerebral haemorrhage. Scott Med f 1992;37:150-2.

13 Logan AStC, Stickle B, O'Keefe N, Hewitson H. Survival following "ecstasy" ingestion with a peak temperature of 42 ${ }^{\circ} \mathrm{C}$. Anaesthesia 1993;48:1017-18.

14 Webb C, Williams V. Ecstasy intoxication: appreciation of complications and the role of dantrolene. Anaesthesia 1993;48:542-3.
15 Tehan B, Hardern R, Bodenham A. Hyperthermia associated with 3,4-methylenedioxyethamphetamine ("Eve"). $A n$ aesthesia 1993;48:507-10.

16 Maxwell DL, Polkey MI, Henry JA. Hyponatraemia and catatonic stupor after taking "ecstasy". BMF 1993;307: 1399.

17 Rothwell PM, Grant R. Cerebral venous sinus thrombosis induced by "ecstasy". $\mathcal{F}$ Neurol Neurosurg Psychiatry 1993; 56:1035.

18 Gledhill JA, Moore DF, Bell D, Henry JA. Subarachnoid haemorrhage associated with MDMA abuse. $f$ Neurol Neurosurg Psychiatry 1993;56:1036-7.

19 Hughes JC, McCabe M, Evans RJ. Intracranial haemorrhage associated with ingestion of "Ecstasy". Archives of Emergency Surgery 1993;10:372-4

20 Levine AJ, Drew S, Rees GM. "Ecstasy" induced pneumomediastinum. $\mathcal{F}$ R Soc Med 1993;83:232-3.

21 Barrett PJ, Taylor GT. "Ecstasy" ingestion: a case report of severe complications. $f R$ Soc Med 1993;83:233-4.

22 Manchanda S, Connolly MJ. Cerebral infarction in association with Ecstasy abuse. Postgrad Med $\mathcal{F} 1993 ; 69$. 874-89.

23 Satchell SC, Connaughton M. Inappropriate antidiuretic hormone secretion and extreme rises in serum creatinine kinase following MDMA ingestion. Br f Hosp Med 1994; 51:495.

24 Kessel B. Hyponatraemia after ingestion of "ecstasy". BMF 1994;308:414.

25 Marsh JC, Abboudi ZH, Gibson FM, Scopes J, Daly S, $\mathrm{O}$ 'Shaunnessy DF, et al. Aplastic anaemia following exposure to 3,4-methylenedioxymethamphetamine ("Ecstasy"). Br F Haematol 1994;88:281-5.

26 Forrest AR, Galloway JH, Marsh ID, Strachan GA, Clark JC. A fatal overdose with 3,4 methylenedioxyamphatamine derivatives. Forensic Sci Int 1994;64:57-9.

27 Greer G, Tolbert A. Subjective reports of the effects of 3 , 4-methylenedioxymethamphetamine in a clinical setting. 4-methylenedioxymethamphetamine in

28 Malmud N, Haymaker W, Custer P. Heat Stroke. A clinicopathologic study of 125 fatal cases. Milit Surg 1946;99. 397-449.

29 Gore I, Isaacson NH. The pathology of hyperpyrexia. Observations at autopsy in 17 cases of fever therapy. $A m \mathcal{F}$ Pathol 1949;25:1029-105.

$30 \mathrm{Kew}$ MC, Tucker RBK, Bersohn I, Seftel HC. The heart in heatstroke. Am Heart $\mathcal{F} 1969 ; 77: 324-35$.

31 Kew M, Bersohn I, Seftel H, Kent G. Liver damage in heatstroke. Am f Med 1970;49:192-202.

32 Bianchi L, Ohnacker H, Beck K, Zimmerli-Ning M. Liver damage in heatstroke and its regression. A biopsy study. Hum Pathol 1972;3:237-48.

33 Chao TC, Sinniah R, Pakiam JE. Acute heat stroke deaths. Pathology 1981;13:145-56.

34 Rubel LR, Ishak KG. The liver in fatal exhertional heatstroke. Liver 1983;3:249-60.

35 Meilke AW, Graybill JR. Fibrinolysis and haemorrhage in heatstroke. $N$ Engl f Med 1967;276:911-13.

36 Weber MB, Blakely JA. The haemorrhagic diathesis of heatstroke. Lancet 1969;i:1190-2.

37 Ginsberg MD, Hertzman M, Schmidt-Nowara WW. Amphetamine intoxication with coagulopathy, hyperthermia reversible renal failure. A syndrome resembling heatstroke. Ann Intern Med 1970;73:81-5.

38 Tucker GT, Lennard MS, Ellis SW, Woods HF, Cho AK, Lin LY, et al. The demethylenation of methylenedioxymethamphetamine ("ecstasy") by debrisoquine hydroxylase (CYP2D6). Biochem Pharmacol 1994;47 1151-6. 